\begin{tabular}{ccr} 
FOLIA & ENTOMOLOGICA & HUNGARICA \\
& ROVARTANI KÖZLEMÉNYEK & \\
Volume 81 & 2020 & pp. $143-153$ \\
\hline
\end{tabular}

\title{
Preparations for the new Checklist of the Diptera of Hungary: Milichiidae
}

\author{
László PAPP
}

H-2200 Monor, Németh Ágoston utca 3, Hungary.E-mail:flyer.papp@gmail.com

\begin{abstract}
Madiza dravensis sp. n., Phyllomyza botulipalpis sp. n., Phyllomyza irinae sp. n. and Phyllomyza kiskunsagiensis sp. n. are described from Hungary. Phyllomyza formicae Schmitz, 1923 is new for the fauna of Hungary. New faunistical data are given for other 13 milichiid species. With 33 figures.
\end{abstract}

Key words - Phyllomyza, Madiza, new species, species new for Hungary

\section{INTRODUCTION}

The latest checklist of Milichidae of Hungary was published by PAPP (2001a). In the frame of preparations for the new (digital) Checklist of the Diptera of Hungary, the unnamed milichiid materials (some 1100 double-mounted adults) accumulated from the Carpathian Basin in the Diptera Collection of the Hungarian Natural History Museum (HNHM, Budapest) were identified in 2019. A few species, listed in PAPP (1978) from Hungary or published later as new for Hungary (PAPP 2001b, 2003), such as Milichia pseudoludens L. Papp, 1977, M. speciosa Meigen, 1830, Milichiella argyrogaster (Perris, 1876), Phyllomyza rubricornis Schmitz, 1923 and Desmometopa varipalpis Malloch, 1927 were not found. Common or less rare species, like Neophyllomyza acyglossa (Villeneuve, 1920), Desmometopa m-nigrum (Zetterstedt, 1848), D. sordida (Fallén, 1820), Leptometopa latipes (Meigen, 1830), L. niveipennis (Strobl, 1900) and Madiza glabra Fallén, 1820 are not mentioned below.

Four species have been found as new to science; it is a surprise in a group which has been better studied than numerous other acalyptrate flies in Hungary. 


\section{TAXONOMY AND FAUNISTIC DATA}

Milichia ludens Wahlberg, 1847 - After the year 2000 the following specimens ( 2 males and 2 females) were collected: 1 male: [Borsod-Abaúj-Zemplén county,] Zempléni TK, Nagyhuta, Rostalló, ernyősökről [from umbellifers], 2007. június 28., Papp L.; 1 female: [Nógrád county,] Karancs-Medves TK, Somoskő[új]falu, Tőke-kút környéke, gyertyános [hornbeam forest], $460 \mathrm{~m}$, 2008. 07. 11., Papp László; 1 female: [Pest county,] Törökbálint, Hosszúrét-völgy, Malaise-csapda [trap], 2012. 05. 20., Lazányi E. \& Soltész Z.; 1 male: [Somogy county,] Somogyszob, Kaszópuszta, Bojsza-tó, nyíres [birch forest], 2007. 06. 05., Papp L. - A rare species also in Hungary.

\section{Phyllomyza botulipalpis sp. $n$.}

(Figs 1-7)

Type material - Holotype male (HNHM, abdomen with genitalia prepared and kept in glycerol in a plastic microvial): [Hungary, Pest county, Nagykovácsi,] Nagyszénás, 500 m, 2011. 05. 30., leg. Peregovits. Paratype male (HNHM): [Hungary, Győr-Moson-Sopron county,] Dél-Hanság, fénycsapda [light trap], 1999. VII. 12. [no more data on label].

Description - Measurements in mm: holotype: body length 2.04, wing length 2.05 , wing width 0.95 ; paratype body length 2.20 , wing length 2.12 , wing width 1.00 .

Frons velvety black, absolutely dull. Palp long and slender, somewhat less definitely sclerotised than that of its relative, Ph. donisthorpei Schmitz, 1923.

Apical scutellars parallel or slightly divergent. Sections R-M to M-M $0.79 \mathrm{~mm}$ (holotype), $0.75 \mathrm{~mm}$ (paratype), terminal section of $\mathrm{M} 3+40.29 \mathrm{~mm}$ (holotype), $0.25 \mathrm{~mm}$ (paratype). Haltere ochre.

Abdomen pale brown.

Male genitalia. Ejaculatory apodeme (Fig. 5) slender. Subepandrial sclerite (Figs 2-3) different from that of $\mathrm{Ph}$. donistorpei. Phallapodeme (Fig. 4) rather different from that of $\mathrm{Ph}$. donisthorpei (Fig. 4, cf. Fig. 10). Surstylus (Figs 6-7) shorter, more rounded and its notch less deep. In addition, the shape of hypandrium (Fig. 1, cf. Fig. 10) also slightly different. Distiphallus mostly membranous like in $\mathrm{Ph}$. donisthorpei.

Differences from the next species can be seen in the male genital parts only.

Etymology - The specific epithet of this new species refers to the sausageshaped palp of the male. 


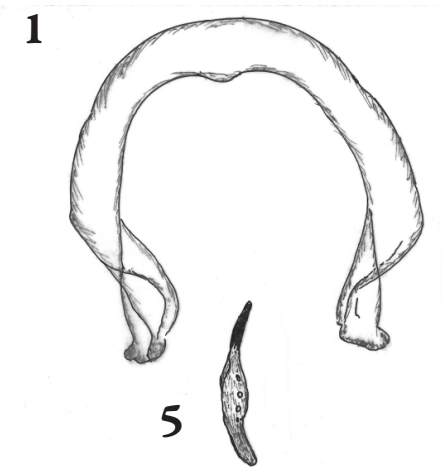

\section{2-3}

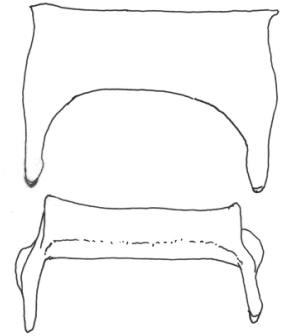

4
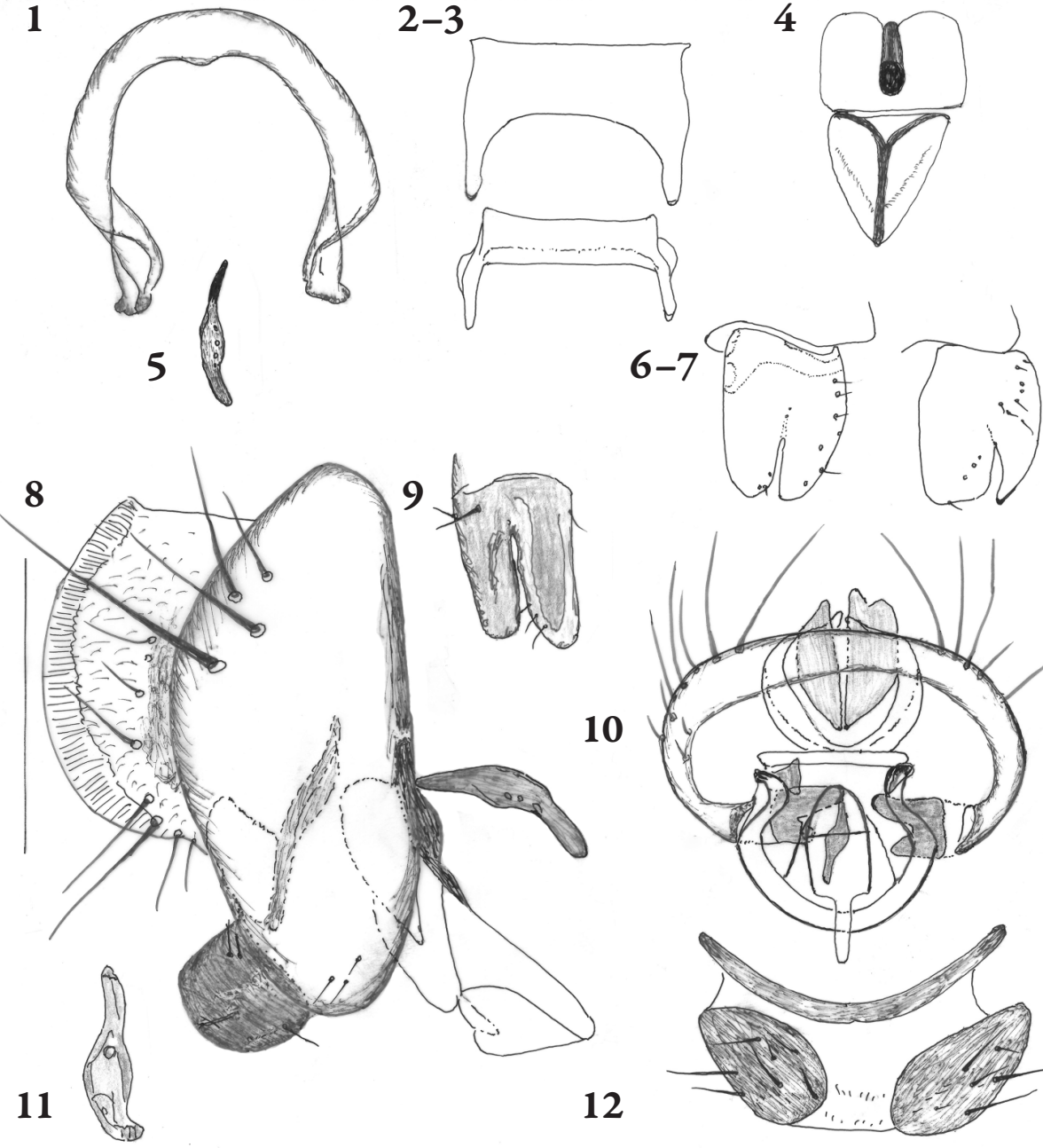

12

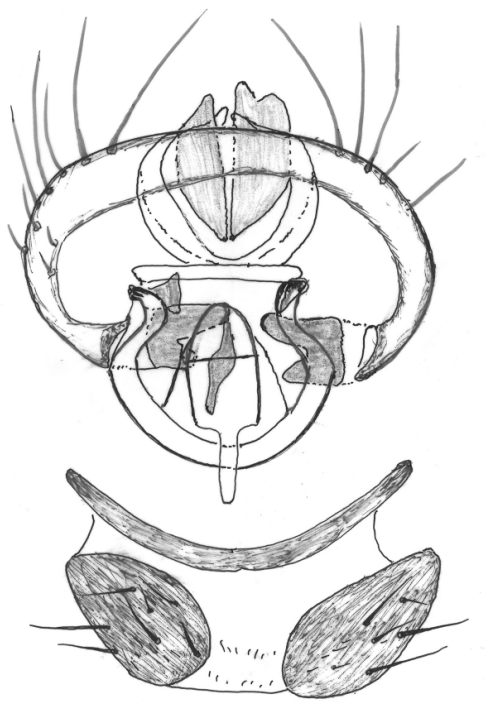

Figs 1-12. Terminalia of Phyllomyza species. 1-7: Ph. botulipalpis sp. n., holotype male, 1 = hypandrium, ventral view, 2-3 = subepandrial sclerite, in two different ventral views, $4=$ phallic complex, ventral view, $5=$ ejaculatory apodeme, $6=$ surstylus, broadest view, 7 = same, lateral-subventral view. 8-12: Ph. donisthorpei Schmitz, male, $8=$ genital complex, lateral view, 9 = surstylus, broadest (subventral-sublateral) view, $10=$ epandrium, hypandrium, cerci, subepandrial sclerite, surstyli and ejaculatory apodeme, ventral view, 11 = ejaculatory apodeme, broadest view, $12=$ pregenital sternites, ventral view. Scale bar $=0.2 \mathrm{~mm}$ for Fig. 10 , 
Phyllomyza donisthorpei Schmitz, 1923 (Figs 8-12) - Twenty-five females were found in the newly identified material, those fit $\mathrm{Ph}$. donisthorpei in the key in PAPP (1978). Six males were with them. However, four males have shorter palp with long thick setae like in Ph. formicae Schmitz, 1923, and two males have long palp, its setulae are minute. This second species is described here as new to science. The palp of $\mathrm{Ph}$. formicae is much shorter and broader, similar to a blade of knife with some marginal setae. The pregenital sternite (Fig. 12) is divided. The surstylus of this species (Figs 8-9) is larger and longer with a deeper notch. Cercus is very large (Fig. 8), phallapodeme is with different shape (Fig. 10, $c f$. Fig. 4) and ejaculatory apodeme broader (Figs 8, 11, cf. Fig. 5). There is only one species which keys with $P h$. donisthorpei, namely Ph. pallida De Meijere. 1929. Unfortunately, only its female holotype is known (De MeIjere 1929). Presently I cannot exclude that $P h$. pallida is a distinct species but I can state that it is not conspecific with the male holotype here.

Phyllomyza equitans (Hendel, 1919) (Figs 13-18) - Hitherto collected and recently identified material: 4 males 14 females: Budapest, Pestszentlőrinc, Péterhalmi-erdő, szajkófészekből [from nest of jay], fenyőn [on pine tree], $8 \mathrm{~m}$, '99. dec. 29-30., Papp; 1 female: ibid., pajzstetves szilfacserjéről [from elm shrub infested with scale insects], 1993. VI. 26., leg. Papp L.; 1 female: ibid., juhar kicsorgó nedvén [from oozing sap of maple], '94. 3. 15. leg. Papp L.; 1 female: [Fejér county,] Velencei-tó, Gárdony, 1951. VI. 2., leg. Soós; 1 female: [Heves county,] Gyöngyössolymos, Cserkő-bánya, Nagy-p. fölött és mellett [above and near the Nagy stream], 260 m, 2008. 06. 11., Papp L.; 1 female: [Somogy county,] Zamárdi, Töreki-láp, 1953. IX. 10., F. Mihályi. - It was originally recorded from Tard (PAPP 1978) but I did not find this specimen among the correctly identified material. So, the voucher specimen may have been misidentified and pinned elsewhere later. This species is less rare than we thought before. New biological data on its life habits are as given above: reared from Garrulus glandarius nest on a Pinus tree (where it was overwintering), collected on oozing sap of a maple tree and captured on elm-tree bush infested by scale insects.

In the course of this study, I found two species which show differences to Ph. equitans but only as regards their male genitalia. They can be identified by the following key.

Figs 13-22. Male genitalia of Phyllomyza species. 13-18: Ph. equitans Hendel, $13=$ hypandrium and phallapodeme, ventral view, $14=$ ejaculatory apodeme, $15=$ hypandrium and phallapodeme, lateral view, $16=$ contours of epandrium, lateral view, $17=$ surstylus, lateral view, $18=$ same, in two different broadest views. 19-22: Ph. irinae sp. n., holotype, $19=$ surstylus, lateral view, $20=$ same, broadest extension, 21 = phallapodeme, lateral view, 22 = hypandrium, phallapodeme, subepandrial sclerite and ejaculatory apodeme, ventral view. Scale bar $=0.1 \mathrm{~mm}$ 


\section{A key for the Phyllomyza Fallén, 1823 species with $0+3 d c$ and apical scutellars divergent (epandrium much longer dorsally than ventrally, Fig. 16)}

1 First flagellomere smaller and rounded. Palp small, definitely shorter than height of facial plate. Male genitalia (Figs 23-27) with surstylus small and rounded, distiphallus longer, hypandrium horse-shoe shaped in ventral view Ph. kiskunsagiensis sp. $n$.

- $\quad$ First flagellomere larger and quadratic. Palp broad and longer than height of facial plate. Male genitalia with surstylus (Figs 17-20) larger and quadratic as for its contour, distiphallus shorter

\section{2}

2 Knees and fore tibia yellowish. Gena broad, c. 1/4 of eye's height. Male genitalia (Figs 17-21) with surstylus larger and broader, free section of phallapodeme slightly longer than its plate, ejaculatory apodeme larger. Hypandrium horse-shoe shaped in ventral view (Fig. 22) Ph. irinae sp. $n$.

- Knees and fore tibia dark brown. Gena narrower, only 1/6 of eye's height. Male genitalia (Figs 12-16) with surstylus smaller and narrower, free section of phallapodeme nearly twice longer than its plate, ejaculatory apodeme smaller. Hypandrium rounded in ventral view (Fig. 13) Ph. equitans (Hendel, 1919)
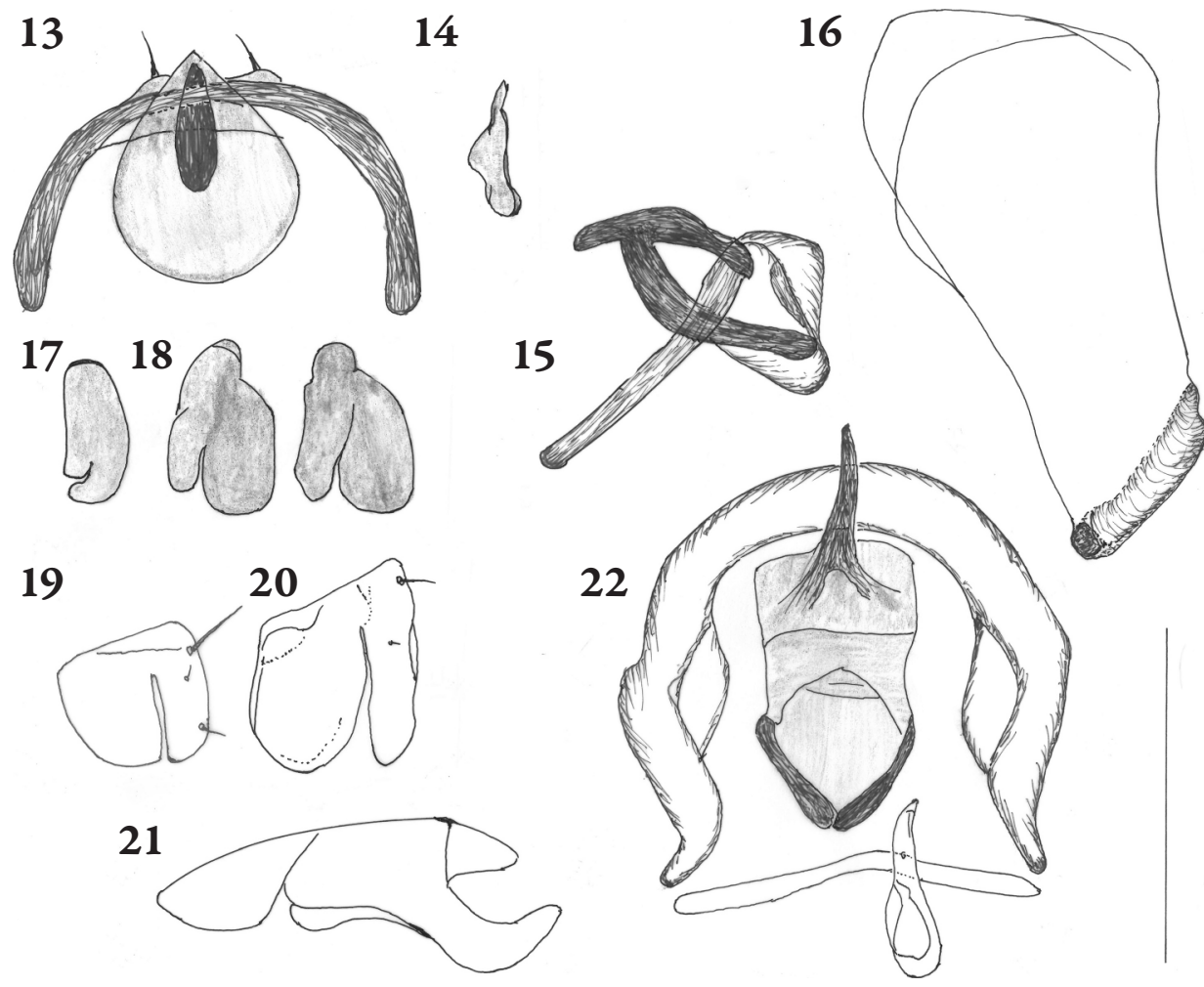


\section{Phyllomyza irinae sp. $n$.}

(Figs 19-22)

Type material - Holotype male (HNHM, abdomen with genitalia prepared and kept in a plastic microvial): [Hungary, Baranya county,] Pécs, Kökény, Malomréti-tó mellett, 2008. 06.23., leg. Papp L.

Description - Body length $1.75 \mathrm{~mm}$, wing length 1.67, wing width 0.90 .

First flagellomere large, quadratic, palp c. $0.37 \mathrm{~mm}$ broad with $0.06 \mathrm{~mm}$ long marginal (ventral) setae. Gena broad, about $1 / 4$ of eye's height.

Penultimate section of M3+4 $0.23 \mathrm{~mm}$, ultimate section $0.81 \mathrm{~mm}$.

Male genitalia. Hypandrium horse-shoe shaped in ventral view (Fig. 22). Surstylus (Figs 19-20) quadratic as for its contours, larger than that of $\mathrm{Ph}$. equitans with deep notch. Ejaculatory apodeme larger (Fig. 22, cf. Fig. 14).

Etymology - The new species is dedicated to Dr Irina Brake (Natural History Museum London) for her unprecedent achievements in the taxonomy of Milichiidae.

\section{Phyllomyza kiskunsagiensis sp. n.}

(Figs 23-27)

Type material - Holotype male (HNHM, abdomen with genitalia prepared and kept in a plastic microvial): [Hungary, Bács-Kiskun county,] KNP [Kiskunság National Park]: Orgovány, homokbuckás [sand hills], nyíres-borókás [birch and juniper stand], 1994. V. 31., Papp L.

Description - Body length: $1.69 \mathrm{~mm}$, wing length $1.62 \mathrm{~mm}$, wing width $0.74 \mathrm{~mm}$.

Gena $0.06 \mathrm{~mm}$, eye's height $0.375 \mathrm{~mm}$, i.e., gena $1 / 6$ of eye's height. First flagellomere smaller and rounded. Palp small, definitely shorter than height of facial plate.

$0+3 \mathrm{dc}$ pairs, anterior pair only $1 / 3$ length of posterior one.

Apical scutellars divergent. Haltere wax-yellow.

Penultimate section of M3+4 $0.23 \mathrm{~mm}$, ultimate section $0.69 \mathrm{~mm}$.

Male genitalia. Hypandrium horse-shoe shaped in ventral view (Fig. 25). Surstylus small and rounded (Fig. 26), distiphallus longer (Figs 23-24), ejaculatory apodeme rather broad and definitely curved (Fig. 27).

Etymology - The specific epithet of the new species refers to its type locality in the Kiskunság National Park. 


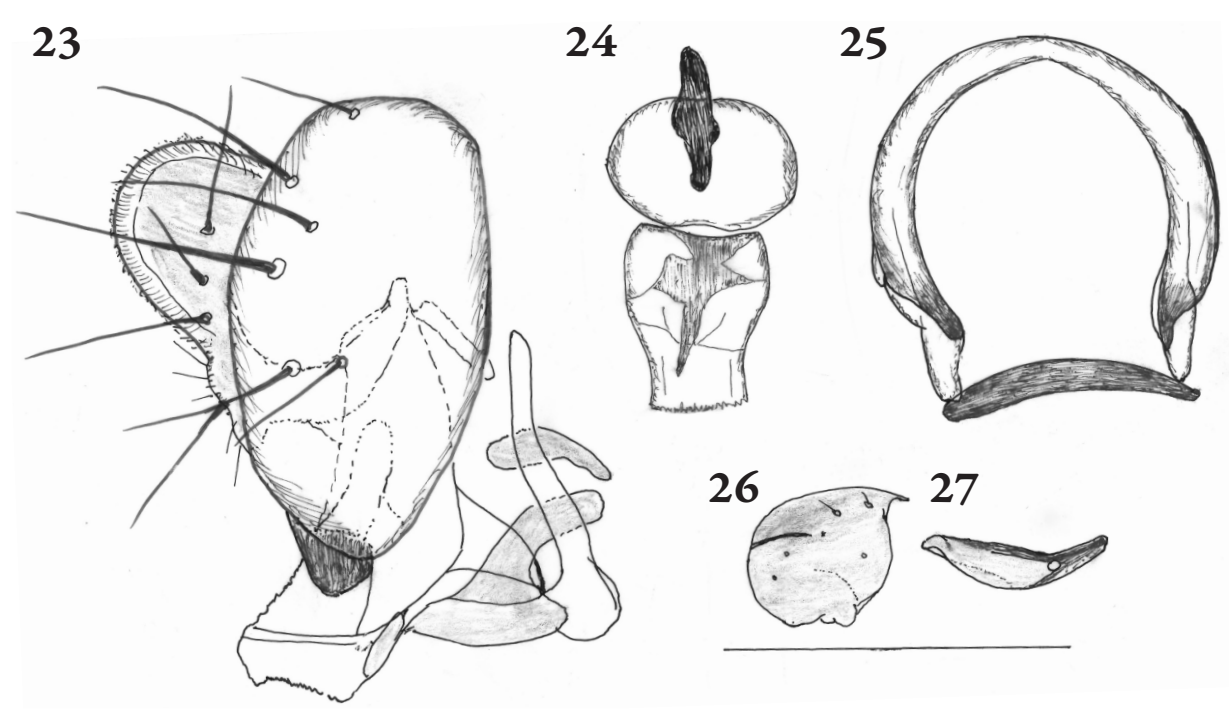

Figs 23-27. Phyllomyza kiskunsagiensis sp. n., holotype, male genitalia, 23 = genital complex, lateral view, $24=$ phallus and phallapodeme, ventral view, 25 = hypandrium and subepandrial sclerite, ventral view, 26 surstylus, broadest view, $27=$ ejaculatory apodeme. Scale bar $=0.1 \mathrm{~mm}$

Phyllomyza flavitarsis (Meigen, 1830) - Recently collected: 1 male: [Baranya county,] Zók-Pázdány, rét [meadow], 2004. 05. 12., leg. Papp L. - A rare species, which must have been misidentified in several cases in the past.

Phyllomyza formicae Schmitz, 1923 - 1 male: Budapest, Pestszentlörinc, Péterhalmi-erdő, forest clearings, May 1, 2017, leg. Papp L.; 1 male, 1 female: [Borsod-Abaúj-Zemplén county,] Kesznyéten, Inéri-háti-rét, 1997. 05. 21-24., leg. Paulovics P. - New for the fauna of Hungary based on the data mentioned above.

Phyllomyza longipalpis (Schmitz, 1924) - Numerous specimens were reared from Vespa crabro nests (PAPP 2000). Other specimens: 3 males, 1 female: [Baranya county,] Kelet-Mecsek TK: Óbánya, Óbányai-(Öreg-)patak, patak fölött és mellett [above and near stream], 2013. 08. 08., leg. Papp L.; 1 male: [Baranya county,] Orfü, Szuadó-völgy, szurdok [gorge], árok alján [in bottom of trench], 2012. 08. 06., leg. Papp L.; 1 female: [Pest county,] Verőce, Magyarkút, Keskenybükki-p., patak fölött és mellett [above and near stream], 2013. 07. 19., leg. Papp L.

Phyllomyza melania (Hendel, 1919) - Newly collected material: 1 male, 1 female: [Baranya county,] Aranyosgadány, Aranyos, 2011. 05. 07., gyümölcsös [orchard], leg. Papp L.; Budapest, Pestszentlőrinc, Péterhalmi-erdő, pajzstetves 
szilfacserjéről [from elm shrub infested with scale insects], 1993. VI. 26. leg. Papp L.; 1 female: [Pest county,] Verőce, Magyarkút, Keskenybükki-patak mellett [near stream], 2006. 06. 04., Papp L.; 1 female: [Pest county,] Szendehely, Nagy-rét, szilvafában Vespa crabro fészek [nest of Vespa crabro in plum tree], 1997. II. 9., kelt [emerged]: 1997. III. 25., leg. Papp L.

Phyllomyza securicornis Fallén, 1823 - Recently detected material in the HNHM: 1 male: Hungaria, Lac Ferto", "Phyllomyza securicornis Fall." Coll. Pokorny.

Phyllomyza tetragona Hendel, 1924-Recently collected specimens of this rare species: 2 males: [Heves county,] Bogács, UV lámpára [at UV light], 2009. 06. 30., leg Papp L.; 1 male: [Pest county,] Nagybörzsöny, Kossuth u., kert [garden], N47.93672 ${ }^{\circ}$ E18.83138, 210 m, 2016. 05. 30., leg. Papp L. \& Soltész Z.; 1 male: [Somogy county,] D.D.N.P. [Danube-Drava National Park]: Darány, borókás [juniper stand], Delelö-kút környéke [vicinity], 2016. 05. 26., leg. Papp L.

Paramyia hungarica L. Papp, 1993 - 45 males, 38 females: Ukraine, Zakarpat'e, Заричне, Nagyágon-túli telep, N48.22944º, E23.27334º, Var-patak mellett [near stream], 2019.07.12., leg. Papp L. \& Papp J. - This is a very interesting finding. After its description based on the single holotype, only another male of the species had been collected. Now a high number of this peculiar species were captured on a dense and high Chaerophyllum aromaticum stand near a streamlet. That is, we seem to find its habitat, at least for the adults.

Desmometopa discipalpis L. Papp, 1993 - It was described based on two males only. In the recently identified material 9 males and 6 females were found, as follows: 1 female: [Baranya county,] Pécs, fcs. [fénycsapda, light trap], 1958. VI. 10., Dr. Wéber; 1 male: [Bács-Kiskun county,] K.N.P. [Kiskunság National Park]: Fülöpháza, Szappan-szék, Malaise-csapda [trap], leg. Papp \& Földvári; 1 female: [Fejér county,] Zámoly, Forráspuszta, birkaürülék [sheep dropping], 1992. VI. 3., leg. Papp L.; 1 male: [Fejér county,] Vértesboglár, Nagy-legelö, juhlegelő [sheep pasture], tálcsapdák [pan traps], 1992. V. 13., leg. Papp L. \& Ádám L.; 1 male (gen. prep.): [Heves county,] Felsőtárkány, 2004.09.25.,leg. Domboróczki G., No.281/1, Fomes fomentarius, kelés [emerged]: 2005. 07. 20.; 2 females: [Pest county,] Szendehely, Keskenybükki-p. v., csigadögökből kelt [emerged from dead snails], 1997. aug. 9.-okt., leg. Papp László; 6 males, 2 females: [Pest county,] Szendehely, Nagy-rét, szilvafában Vespa crabro fészek [nest of Vespa crabro in plum tree], 1997. II. 9., kelt [emerged]: 1997. III. 25-26., leg. Papp L. - Most of the above specimens were formerly misidentified and published as D. sordida (Fallén, 1820). It is apparently an opportunistic species. Its original description is supplemented as follow: Male with very large first flagellomere with dense grey microcilia, palp with longer setae than on Fig. 1 of PA PP (1993). Haltere greyish yellow (not stated in the original description). BRAKE (2009) discussed its species identity. 
Madiza britannica Hennig, 1937 - Recently identified specimens: 1 female: [Baranya county,] Kelet-Mecsek TK [Landscape Park], Óbánya, Óbányai-patak fölött, mellett [above and near stream], 2002. 05. 28., Papp L.; 1 male (gen. prep.): [Borsod-Abaúj-Zemplén county,] Bükk NP [National Park]: Odvaskő, bükkös [beech forest], 1979. VI. 12., leg. Bajza Zs. \& Papp; 3 males, 2 females: [BorsodAbaúj-Zemplén county,] Zempléni TK [Landscape Park]: Nagyhuta, Kőkapu, ernyős virágokról [from umbellifers], 2005. 7. 13., Szappanos; 1 female: ibid., Rostalló, ernyősökről [from umbellifers], 2007. június 26., Papp L.; 1 female: [Nógrád county,] Nógrádszakál, Ráróspuszta, tölgyes [oak forest], dagonya körül [around mud wallow], 2003. május 30., leg. Papp L.; 1 male: [Pest county,] Verőce, Magyarkút, Keskenybükki-p. v., ernyősökről [from umbellifers], 2001. júl. 26, leg. Papp L.; 1 male, 1 female: [Pest county,] D.I.N.P. [Danube-Ipoly National Park]: Szokolya, Les-völgy, patak fölött, mellett [above and near stream], 2005. 06. 25., Papp L.

Madiza eximia L. Papp, 1993 - Recently identified specimens: 1 female: [Baranya county,] Komló, Mánfa, Kölik környéke [vicinity], patak fölött, mellett [above and near stream], '09. 06. 03., leg. Papp L.; 1 male, 1 female: [Borsod-AbaújZemplén county,] Zempléni TK [Landscape Park]: Bózsva, Senyő-völgy, korhadt nedves fák [rotten wet wood], 1998. 05. 20., leg. Papp L.; 1 male (gen. prep.): [Borsod-Abaúj-Zemplén county,] Zempléni TK [Landscape Park]: Nagyhuta, Kőkapu, ernyős virágokról [from umbellifers], 2005. 7. 13., Szappanos; 1 female: [Borsod-Abaúj-Zemplén county,] Zempléni TK [Landscape Park]: Füzér, Nagy-p. fölött és mellett [above and near stream], 2005. 06. 21., leg. Papp L., Földvári M.; 1 female: [Borsod-Abaúj-Zemplén county,] B.N.P. [Bükk National Park]: Varbó, Dobrica-f. környéke [vicinity], 2004. 05. 26., Papp L.

Madiza pachymera Becker, 1908 - In the Diptera Collection of the HNHM, besides the holotype, there are 28 males and 17 females, which were identified in the course of the present project. Of them, 5 males and 14 females were collected

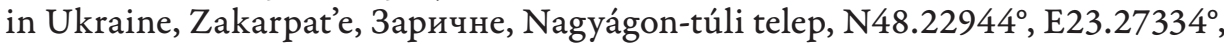
Var-patak mellett [near stream], 2019. 07. 12., leg. Papp L. \& Papp János. Others were collected in the Bükk Mts, Mátra Mts, Mecsek Mts, Zempléni Mts and at Gyékényes (Lankóci-erdő [forest]) in June and July.

\section{Madiza dravensis sp. $n$.}

(Figs 28-33)

Type material - Holotype male: [Hungary, Somogy county,] D.D.N.P. [Danube-Drava National Park]: Berzence, Lankóci-erdő, tölgyes [oak forest], 2009. 06. 12., leg. Papp L. Paratypes: 2 males with the same data (one of them with abdomen and genitalia prepared and kept in glycerol in a plastic microvial). 
Description - Measurements in mm: body length 1.69 (holotype), 1.71 (paratypes), wing length 1.51 (holotype), 1.45 (paratypes), wing width 0.65 (holotype), 0.61, 0.70 (paratypes).

Frons dull black. Fore coxa not lengthened. Apex of fore coxa and both ends of fore femur yellowish.

$\mathrm{R}-\mathrm{M}$ to $\mathrm{M}-\mathrm{M}$ section $0.75,0.81$, ultimate section of $\mathrm{M} 3+40.24 \mathrm{~mm}$ (all).

Distal part of tergite 5 with rather long triplets of setulae (Fig. 30).

Male genitalia. Epandrium slightly higher than broad in caudal view (Figs 28, 31). Cercus medium long with short or medium long setae only (Fig. 31, cf. BR A KE 2009). Surstylus (Figs 28-29, 31) longer than broad with 2 longitudinal medium edge. Hypandrial complex long, more or less boat-shaped, hypandrium with a pair of strong setae. Basiphallus ovoid in ventral view (Fig. 32), somewhat less than twice longer than high in lateral view (Fig. 33). Distiphallus large, weakly sclerotised (Fig. 33).

Comparative notes - There is only another species with dull frons among the European Madiza species (PAPP 1993), namely M. pachymera Becker, 1908. In contrast to this new species its body is larger, male fore coxa is extremely lengthened. That is, it is easy to identify this new species, whose long triplets of setulae distally on tergite 5 are also very characteristic.

Etymology - The specific epithet of the new species refers to its type locality in the Danube-Drava National Park.

28

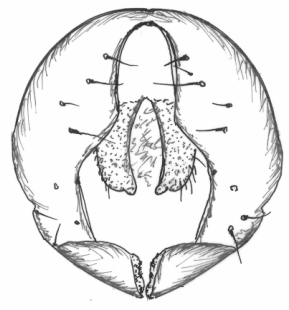

32

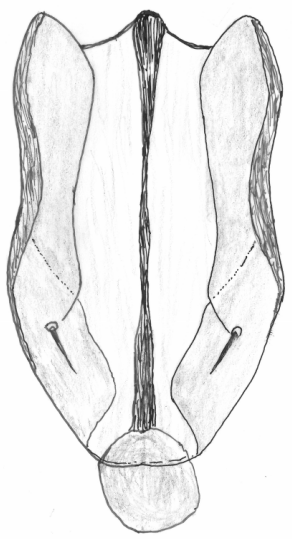

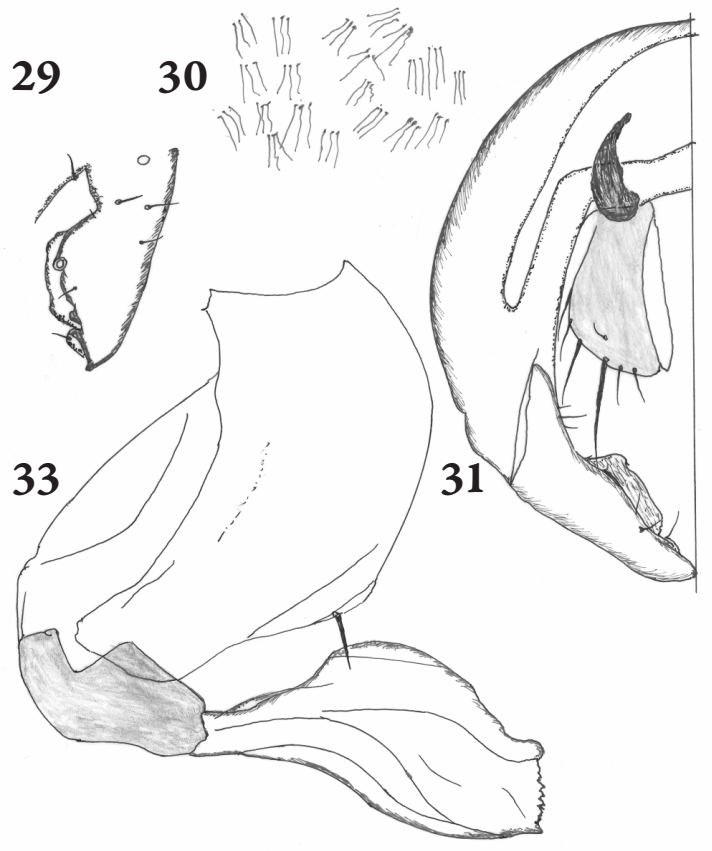




\section{REFERENCES}

BRA KE I. 2009: The type material of Milichiidae and Carnidae (Insecta: Diptera: Schizophora) in the Naturhistorisches Museum Wien. - Annalen des Naturbistorischen Museums in Wien, Serie B 110: 67-76.

De Meijere J. C. H. 1940: Eine neue myrmecophile Phyllomyza, Phyllomyza pallida n. sp. Entomologische Berichten Amsterdam 10(232): 222-223.

PAPP L. 1978: 72. család: Milichiidae - Pákosztoslegyek. - In: Magyarország Állatvilága (Fauna Hungariae), XV, 9. Akadémiai Kiadó, Budapest, pp. 9-32.

PAPP L. 1993: Three new milichiid species (Diptera, Milichiidae) from Hungary. - Annales historico-naturales Musei nationalis hungarici. 85: 133-139.

PAPP L. 2000: Diptera reared from Vespa crabro nests in Hungary. - Folia entomologica hungarica 61: 215-218.

PAPP L. 2001a: Milichiidae. - In: PAPP L. (ed.): Checklist of the Diptera of Hungary. Hungarian Natural History Museum, Budapest, pp. 327-329.

PAPP L. 2001b: Cyclorrhaphan flies (Diptera) new for the fauna of Hungary. - Folia entomologica hungarica 62: 283-292.

PAPP L. 2003: Further additions and corrections to the Hungarian checklist (Diptera). - Folia entomologica bungarica 64: 309-339.

Figs 28-33. Madiza dravensis sp. n., holotype, male abdomen and genitalia, $28=$ epandrium, cerci and surstyli, caudal view, 29 = surstylus, broadest extension, $30=$ setulae on tergal plate, $31=$ epandrium, cercus, surstylus and ejaculatory apodeme, anterior view, 32 = hypandrium and basiphallus, ventral view, 33 = hypandrium and phallus, lateral view. Scale bar $=0.2 \mathrm{~mm}$ for Fig. 28, $0.1 \mathrm{~mm}$ for Figs 29-33 